\title{
BOTTOM WATER FORMATION AND POLYNYAS IN ADÉLIE LAND, ANTARCTICA
}

\author{
by Nathaniel L. Bindoff, Stephen R. Rintoul and Robert Massom
}

(with five text-figures)

Bindoff, N.L., Rintoul, S.R. \& Massom, R., 2000 (31:v): Bottom water formation and polynyas in Adélie Land, Antarctica. In Banks, M.R. \& Brown,M.J.(Eds): TASMANIA AND THE SOUTHERNOCEAN. Pap. Proc. R. Soc. Tasm. 133(3):51-56.

https://doi.org/10.26749/rstpp.133.3.51 ISSN 0080- 47GJ. Antarctic CRC, GPO Box 252-80, Hobart, Tasmania, Australia 7001 (NLB, SRR, RM); and CSIRO Division of Marine Research, GPO Box 1538, Hobart, Tasmania, Australia 7001 (SRR).

Antarctic Bottom Water is the coldest and densest water found in the global ocean. It spreads into all the major ocean basins, carrying the cold water towards the equatorial regions, and is a central component of the global thermo-haline circulation. However, the mechanisms of bottom water formation are not well established; its geographical distribution and rate of formation have yet to be fully quantified.

Polynyas, which are large persistent openings in sea-ice that form during the winter near the Antarctic Coast, play a central role in the formation of Antarctic Bottom Water.

This paper describes the bottom water formation around the Antarctic continental margin with particular emphasis on the prøcesses and mechanisms of the Adélie Land Bottom Water formation near Dumont D'Urville south of Tasmania.

Key Words: Antarctic Bottom Water, polynya, brine rejection, Adelie Land Bottom Water.

\section{INTRODUCTION}

Antarctic Bottom Water (AABW) is one of the most important water-masses in the global ocean. It is the coldest, densest water found in the deep ocean. This water is found in all of the deep basins around the Antarctic continent, broken only by the relatively shallow sill through Drake Passage. Estimates of the volume of AABW (defined by water denser than neutral density - Jackett \& McDougall $1997\left[\gamma^{n}>28.27 \mathrm{~kg} . \mathrm{m}^{-3}\right]$ ) show it to occupy $3.5 \%$ of the volume of the ocean (Orsi et al. 1999) and affect, through mixing and advection, more than $41 \%$ of the global oceanic volume (Worthington 1981). Estimates of the production rate of bottom water vary but range from $8-12 \mathrm{~Sv}$ (Orsi et al. $1999\left[1 \mathrm{~Sv}=10^{6} \mathrm{~m}^{3} \cdot \mathrm{s}^{-1}\right]$ ), giving a renewal time (defined here as the volume occupied by AABW divided by production rate) of 180-120 years, respectively. This renewal time is quite long, reflecting the fact that the production rate is small compared with the volume of the ocean occupied by $\mathrm{AABW}$. Yet it is this production rate combined with the relatively low mixing rates which creates the strong density gradients that define the Antarctic Circumpolar Current.

The main formation of $\mathrm{AABW}$ is thought to occur in three distinct regions, on the continental shelves of the western Weddell Sea, western Ross Sea and Adélie Land, south of Tasmania. The Adélie Land source of bottom water has always been considered to be negligible (Carmack 1977) compared with the Weddell and Ross Sea sources. However, recent analyses of the volume of the AABW characteristic of these three source regions show that the Weddell, Adélie and Ross sources are respectively 68\%, $24 \%$ and $8 \%$ by volume (Rintoul 1998), that is Adélie Land Bottom Water (ADLBW) is the second largest source. This new result is also supported by a census of Chlorofluorocarbon (CFC-11) concentrations around the Antarctic continent (Orsi et al. 1999), which shows that layer of AABW defined by the CFC-11 is thicker in the
Australian-Antarctic basin than in either the Weddell or Ross Seas.

Bottom waters are an important part of the thermohaline circulation, and increased greenhouse gas scenarios from coupled-ocean-atmosphere models show that the rate of bottom water formation is expected to decrease (Manabe et al. 1990, Manabe et al. 1991). It is important that these model scenarios are validated with observations. In this paper the geographical distribution of ADLBW in the Australian-Antarctic basin, evidence for its time variability of formation and its links to the Mertz Polynya are described.

\section{BOTTOM WATERS IN THE AUSTRALIAN-ANTARCTIC BASIN}

Describing the precise distribution of bottom waters and estimating their production are essential requirements for understanding the mechanisms and sources of bottom water formation. The CFC-11 concentration at $10 \mathrm{~m}$ above the ocean floor (fig. 1) is taken from hydrographic data obtained on a voyage of the RSV Aurora Australis from JanuaryMarch 1996 (see Bindoff et al. 1997 and Rosenberg et al. 1997 for a more complete description of this voyage). These CFC-11 measurements are accurate to $-1 \%$ (WOCE standard). Although the source of CFC-11 in the atmosphere is increasing, the rate of increase from 1990 to 1996 is just $6 \%$ or about $1 \%$ per year (Gras et al. 1999). Thus, for the relatively young waters directly above the ocean floor and the shelf waters presented here ( $<10$ years old) there is no need to adjust the CFC-11 values to allow for the time variation in the atmospheric source, and for these data this adjustment is small compared to the effects of mixing. The CFC-11 Chloro-fluorocarbons are transferred from the atmosphere to the oceans through the surface of the ocean. Because CFCs are chemically passive in the ocean, they act as a tracer or dye. The highest concentrations (to first order) 


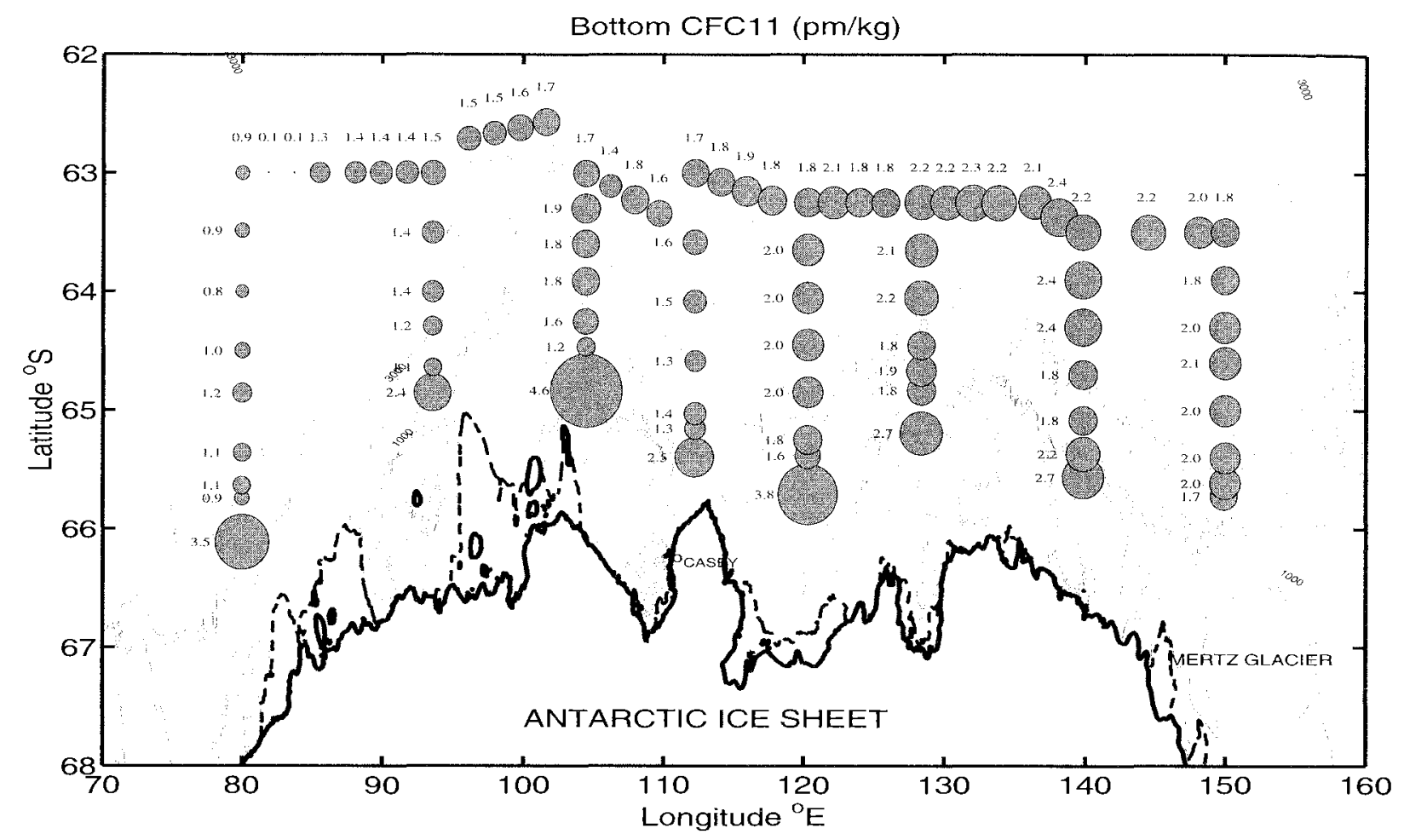

FIG. 1 - The CFC-11 concentration (pmollkg) taken from the deepest water sample (typically $10 \mathrm{~m}$ from bottom) for all CTD stations over the deep ocean. The numbers are the observed CFC-11 concentration at each CTD. The size of the circle gives the amplitude of the CFC-11 concentration. The 1000 and $3000 \mathrm{~m}$ depth contours are shown. These data come from the MARGINEX experiment (Bindoffet al. 1997), obtained in January-March 1996. The thick dashed contours show the ice shelves in this region.

can be interpreted here as waters that have been most recently in contact with the atmosphere. Each of the north-south hydrographic sections (except at $150^{\circ} \mathrm{E}$ ) cross the continental shelf break shown by the $500 \mathrm{~m}$ isobath. On the shelf floor, very high CFC- 11 concentrations of greater than 4 pmol. $\mathrm{kg}^{-1}$ occur, consistent with the moderately rapid overturning of the shelf waters and mixing with the atmosphere. However, these concentrations decrease very rapidly down the continental slope. In the deep ocean, the lowest deep-water CFC- 11 concentrations occur in the west (along $80^{\circ} \mathrm{E}$ ) with concentrations less than $1 \mathrm{pmol} . \mathrm{kg}^{-1}$, and these concentrations progressively increase eastward until a local maximum in CFC- 11 concentration occurs at $140^{\circ} \mathrm{E}$.

At $150^{\circ} \mathrm{E}$ the $\mathrm{CFC}-11$ concentration decreases again. These lower CFC-11 concentrations are also accompanied by higher salinities and warmer temperatures, consistent with this water originating from the Ross Sea and flowing westwards along the continental rise (Gordon \& Tchernia 1972). The increase in CFC- 11 at $140^{\circ} \mathrm{E}$ also accompanies water that is colder, fresher and more oxygen-rich, implying that the bottom waters at $140^{\circ} \mathrm{E}$ have been mixed with more recently ventilated water originating from the continental shelf somewhere between $140^{\circ}$ and $150^{\circ} \mathrm{E}$.

Excluding the large values of CFC-11 over the continental shelf/slope break (less than $1000 \mathrm{~m}$ ), all of the north-south sections show the highest values of CFC-11 (and also the coldest, freshest and highest in oxygen) offshore in waters deeper than $3000 \mathrm{~m}$ (fig. 1). Although it appears from these data that the source must be between $140^{\circ}$ and $150^{\circ} \mathrm{E}$, it is clear that during the summer time there is not a continuous plume of high CFC (cold and fresh and dense) water flowing downslope in either of these two sections. This suggests that the source waters are flowing down the continental slope during the winter or between the two sections or in discrete canyons on the continental slope (Rintoul 1998).

The seasonal variability of bottom water formation is poorly known because the extensive sea-ice cover during winter makes the continental slope and shelf region largely inaccessible to conventional ship-based measurements. However, temperature measurements from $10 \mathrm{~m}$ above the ocean bottom from a mooring at $65^{\circ} \mathrm{S}, 140^{\circ} \mathrm{E}$ in $2600 \mathrm{~m}$ of water show a distinctive seasonal signal. The warmest temperatures occur during the February-June period and the strongest cooling in the August-December period (Fukamachi, pers. comm.); this is consistent with the strongest formation being during the late winter-spring.

In addition, the temperature and salinity characteristics of shelf waters during the January-March 1996 voyage of the RV Aurora Australis show that the shelf salinities (fig. 2A) are too fresh to form bottom waters, supporting the conclusions from the moored temperature measurements. Although the Ross Sea Bottom Water (RSBW) has distinctive temperature and salinity characteristics present at $150^{\circ} \mathrm{E}$, there is no evidence for this signature at $128^{\circ} \mathrm{E}$ (fig. 2A), where the bottom waters are colder and fresher (labelled as ADLBW). Here, the temperature--salinity correlation for waters $<0^{\circ} \mathrm{C}$ forms a straight line that is noise free (fig. $2 \mathrm{~A}$ ). The shelf waters have a temperature near the surface freezing temperature $\left(-1.85^{\circ} \mathrm{C}\right)$ and a salinity less than $34.5 \mathrm{psu}$. For this section there is no simple two-end member mixing scheme between the 
summer shelf waters with the Modified Circumpolar Deep Water (labelled MCDW) and the ADLBW. By contrast, the CFC-cemperature correlation shows a different relationship between the shelf water and ADLBW (fig. 2B). The shelf vaters at $\left(-1.85^{\circ} \mathrm{C}\right)$, the MCDW and the bottom waters $\left(\angle 0^{\circ} \mathrm{C}\right)$ lie along a single straight line. This suggests that in the source region the shelf waters are mixing with MCDW to form bottom water approximately consistent with a two-end member mixing scheme.

Such a tro-end member mixing scheme also implies that the shelf salinity during formation of these bottom waters must have been at least as high as 34.63 psu. Typically, the bottom salinity on the continental shelf is 34.4 to $34.5 \mathrm{psu}$ (excluding depressions on the shelf where relict winter water may remain - Gordon \& Tchernia 1972, Rintoul 1998). Thus, to form ADLBW a source of salinity is required during winter to increase the bottom salinity on the shelf by at least 0.15 psu.

\section{ON-SHELF TRANSPORT OF MODIFIED CIRCUMPOLAR DEEP WATER}

There are two processes for increasing the salinity of shelf waters. The first is through the transport of relatively warm and salty MCDW (fig. 2A) onto the continental shelf (primarily through channels through the shelf break) and the second is through brine rejection from the formation of sea-ice.

Although there are relatively few hydrographic observations on the continental shelf region between $140^{\circ}$ and $150^{\circ} \mathrm{E}$, there is some evidence from earlier measurements that during summer, MCDW does penetrate onto the continental shelf. MCDW is characterised by a shallow temperature maximum (and salinity maximum). Offshore over the continental slope (north of the $500 \mathrm{~m}$ isobath) the temperature maximum is relatively warm (between $-0.5^{\circ}$ and $0.5^{\circ} \mathrm{C}$ ) and is present along the entire slope between $140^{\circ}$ and $150^{\circ} \mathrm{E}$ (fig. 3). With the exception of the Adélie Depression $\left(142^{\circ}-145^{\circ} \mathrm{E}\right)$, this temperature maximum is always colder than $-1.0^{\circ} \mathrm{C}$ for hydrographic casts south of the $500 \mathrm{~m}$ isobath, indicating that very little of the warm MCDW over the continental slope manages to cross the shelf break. However, in the Adélie Depression, the temperature maximum is much warmer (temperatures between $-1.0^{\circ}$ and $0.5^{\circ} \mathrm{C}$ ) and even higher in the entrance, suggesting a significant onshore flow through the depression in the shelf break at $143^{\circ} \mathrm{E}$. Because MCDW is relatively saline compared with the relatively fresh shelf waters (fig. 2), the inflow of this water provides a source of high-salinity water for the formation of bottom water.

\section{ROLE OF POLYNYAS IN BOTTOM WATER FORMATION}

Polynyas, which are large persistent openings in sea-ice that form during the winter near the Antarctic Coast, play a central role in the formation of AABW. They are active regions of sea-ice formation, because the cold Antarctic winds $\left(<-30^{\circ} \mathrm{C}\right.$ and average speeds in excess of $\left.25 \mathrm{~m} . \mathrm{s}^{-1}\right)$ freeze the surface waters and then blow this newly formed ice away from the coast. It is this transport of sea-ice from the coast and the shape of the coastline that keep the polynyas open and make these open areas a factor of ten greater in ice production compared with ocean covered in sea-ice ( $Z$ wally et al. 1985).

The high release of heat to the atmosphere and the high sea-ice production both act to increase the density of the waters below the polynya. In some polynyas, where the bottom topography has an ideal shape, the brine rejection during ice-formation in combination with the on-shelf flow of saline waters from offshore increases the salinity of the water column. When the shelf salinity reaches a critical
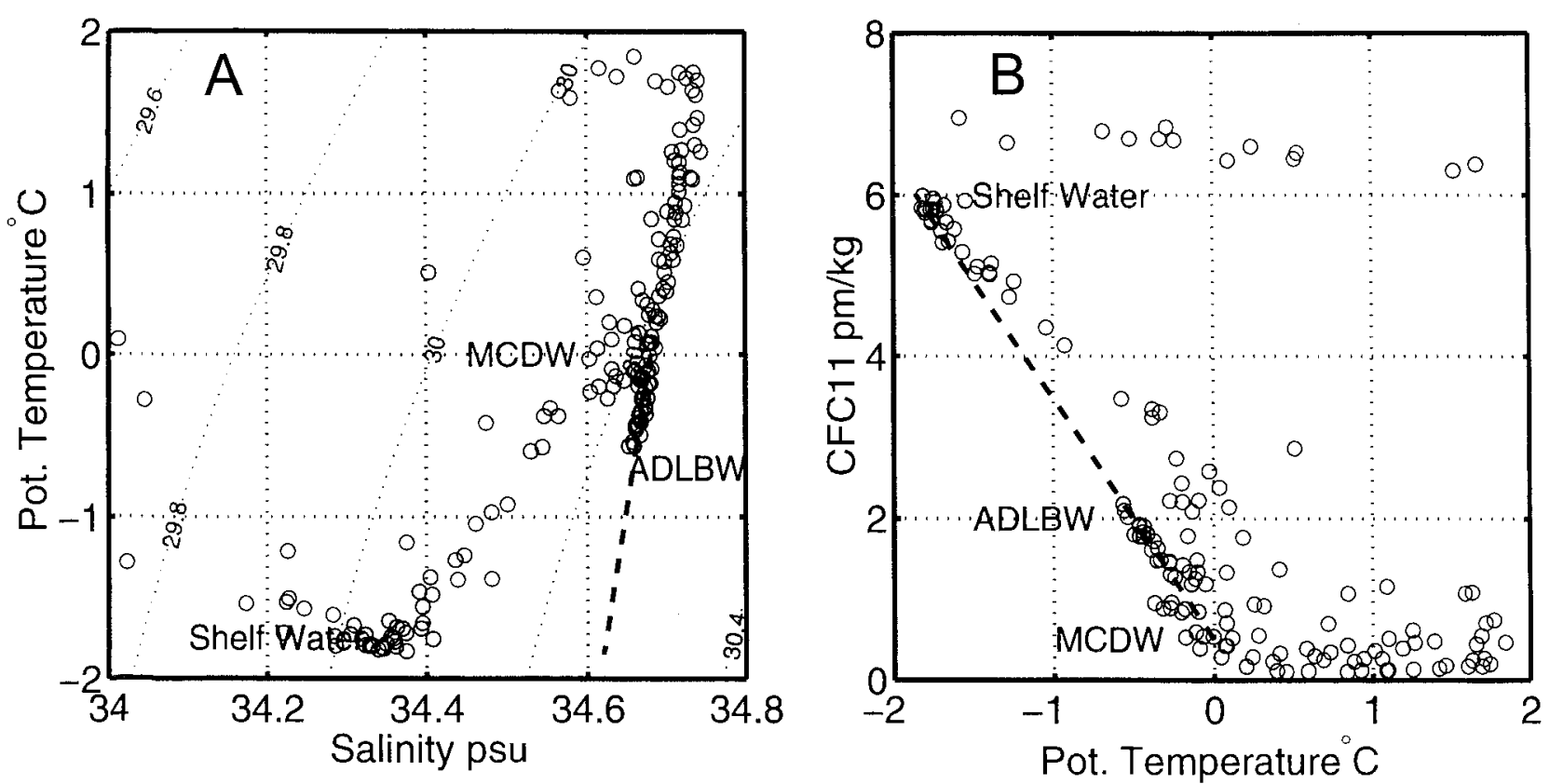

FIG. 2 - Property property plots of (A) potential temperature and salinity, (B) observed CFC-11 (pmollkg) and potential temperature. These property-property plots are from the individual water samples from the bydrographic section taken along $128^{\circ} \mathrm{E}$ in figure 1. 
value, these shelf waters become dense enough to flow down the continental shelf to the abyss. The principal reasons for the uncertainties in bottom water formation are that difect observations of the processes are difficult to make from ship and satellite, and that the strongest formation period is believed to be when the sea-ice is at its greatest extent around the Antarctic continent (i.e. September-October).

Brinerejection during sea-ice formation also plays a role in increasing the winter time salinity. A detailed census of the significant polynyas between $40^{\circ}$ and $160^{\circ} \mathrm{E}$ over an eight-year period, using satellite passive microwave data, shows that the largest and most persistent polynyas are the Shackleton Ice Shelf and the Mertz Polynyas with respectively an average area in winter of 30000 and $23000 \mathrm{~km}^{2}$ (Massom et al. 1998). However, in spite of its larger size the Shackleton Ice Shelf (near $95^{\circ} \mathrm{E}$ ) is not associated with bottom water formation (fig. 1). The factors that affect production are not the size of the polynya alone, but also include the strength and direction of the local winds, air temperature and water temperature. Along the Antarctic coastline, the Mertz Polynya $\left(67^{\circ} \mathrm{S}, 145^{\circ} \mathrm{E}\right)$ is in a region of some of the world's strongest and most persistent winds (Adol phs \& Wendler 1995, Ball 1957). It is these factors that give rise to the Mertz Polynya having what is believed to be the greatest ice production in East Antarctica (Cavalieri \& Martin 1985).

The Mertz Polynya lies immediately above the Adélie Depression (cf. fig. 4 with fig. 1). This polynya forms to the west of the Mertz Glacier. Its size is also partly controlled by the line of grounded icebergs and fast ice that extends north from this glacier (at $146^{\circ} \mathrm{E}$ ), blocking the westward flow of sea-ice into the sea-ice area. The katabatic winds are strongly offshore at the coastline, turning westwards in 20 $30 \mathrm{~km}$. However, the ice-free region extends well beyond the zone of strong winds, and this polynya is wider than most (Massom et al. 1998). The unusual width of this polynya is also associated with this region becoming icefree earlier in the spring than the regions immediately to the east and west (Gloersen et al. 1992, Massom et al. 1998) and may be the result of the upwelling of warm MCDW in the polynya region. This polynya has a strong seasonal signal (fig. 5) with its areal extent becoming largest typically in October and ranging from 20000 to $60000 \mathrm{~km}^{2}$ for this month. The fastest rate of growth in size of this polynya tends to occur during AugustSeptember, which is consistent with maximum sea-ice production and coincides with the colder bottom waters observed in temperature time-series measured offshore (Fuchamachi, pers. com.).

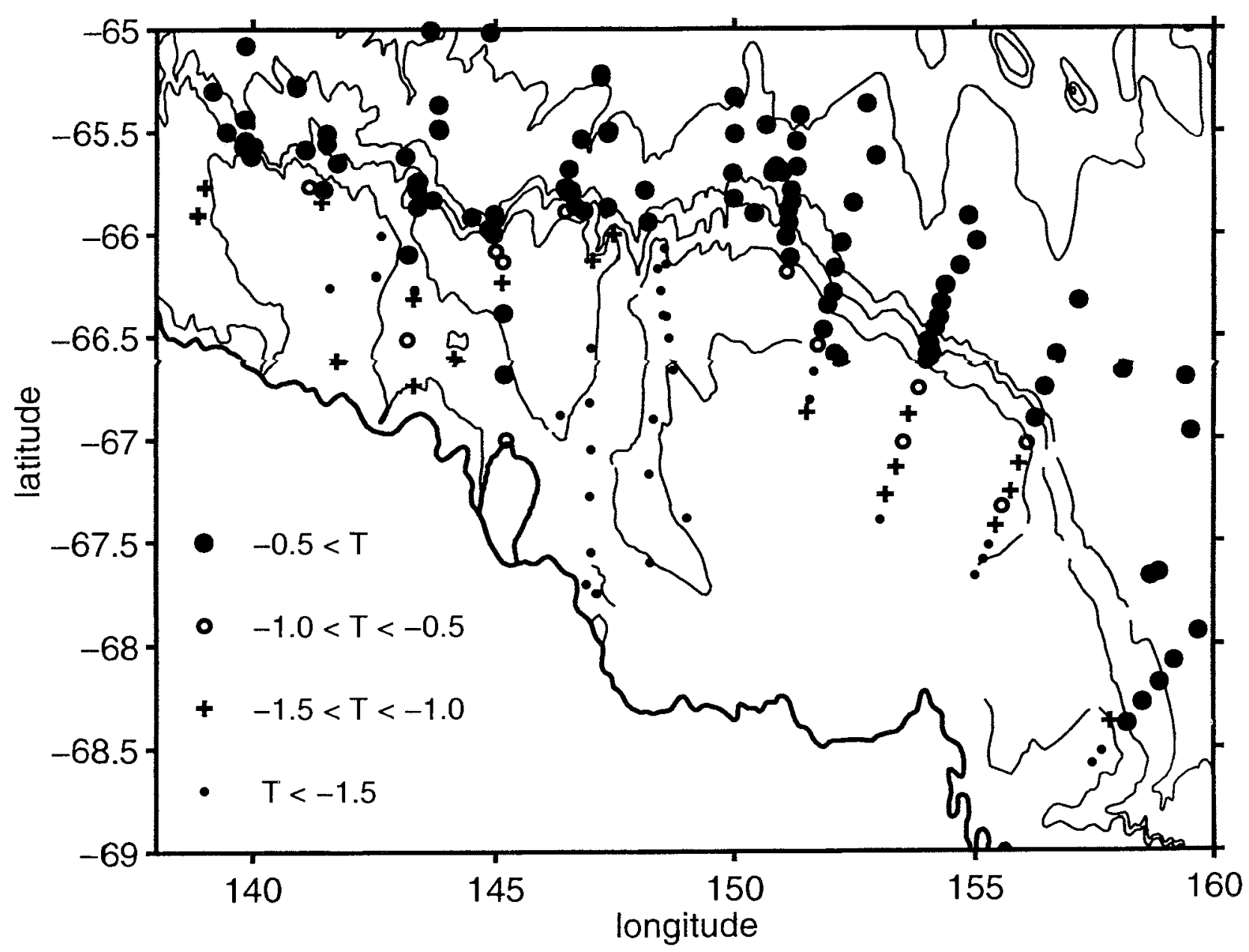

FIG. 3 - The potential temperature of the potential temperature maximum of MCDW plotted using the available historical data. The 500,1000, 2000 and $3000 \mathrm{~m}$ isobaths are shown. Note that the warmest MCDW on the shelf is found in the Adelie depression between $143^{\circ}$ and $145^{\circ} \mathrm{E}$. 


\section{CONCLUSIONS}

From th esedata, the Mertz Polynya appears to play a central role in the formation of ADLBW. It provides additional salinity through high sea-ice production and, because of the cold air temperatures, provides a window for high heatfluxes from the ocean to the atmosphere. These high heatfluxes can cool the likely onshore transport of warm (and relatively more saline) MCDW waters, thereby enhancing the overturning circulation within the Adélie Depression caused by the outflow of cold bottom water. In this conceptual model, the Mertz Polynya is being kept open by the winds (i.e. acting as a latent heat polynya) and also by heat transported onshore by MCDW (i.e. acting as a sensible heat polynya). The fact that no MCDW is observed on the continental shelf except in the Adélie Depression also

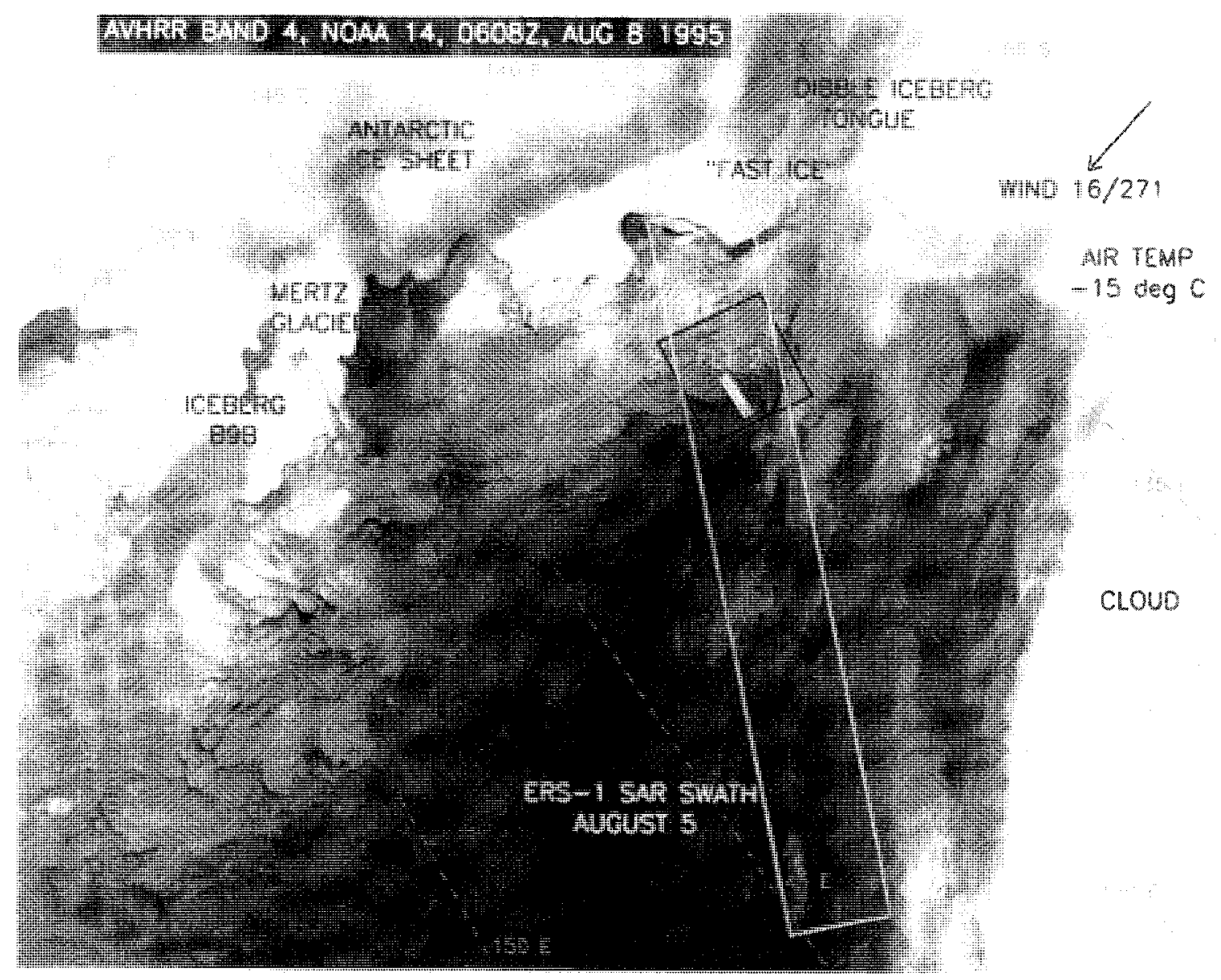

FIG. 4-An AVHRR channel 4 (thermal infrared) image of the Antarctic coastline taken in August 1995 between $150^{\circ}$ and $135^{\circ}$, south of Tasmania. The Mertz Polynya is the dark region to the west of the Mertz Glacier and adjacent to the Antarctic coastline. The grey-scale gives an indication of the temperature, with the brightest greys corresponding to the coldest reflective surface (glacier ice or clouds) and the darkest regions to open ocean.

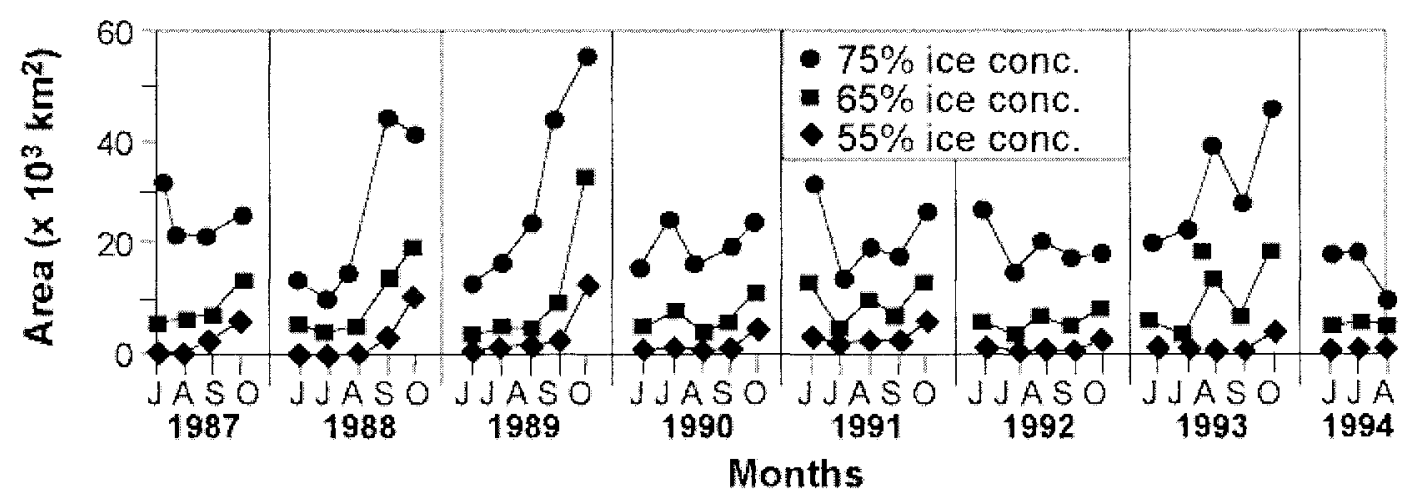

FIG. 5-Eight-year time series of the area of the Mertz Polynya as determined from the Special Sensor Microwave Image satellite passive microwave observations. The polynya is deemed to be an open area when the sea-ice concentration falls below a specified concentration. In this figure, the open area was determined for three cases where the concentrations are respectively less than $75 \%$, 65\% and 55\%. From Massom et al. (1998) 
indicates that the shape of the Adélie Depression and its associated channel through the shelf break is a critical element in the formation of ADLBW.

The essential questions that need to be resolved are the precise role that the onshore transport of MCDW plays compared with the role of ice production within the Mertz Polynya and the rate of production of Adélie Land Bottom Water. These questions are being addressed through a multidisciplinary programme involving sea-ice scientists, meteorologists and oceanographers in July 1999.

\section{ACKNOWLEDGEMENTS}

The hard work of the Master and crew on the RV Aurora Australis is greatly appreciated. The CFC data were kindly made available by Dr Mark Warner, School of Oceanography, University of Washington, U.S.A. This work is a contribution to the World Ocean Circulation Experiment and the CSIRO Climate Change Research Program.

\section{REFERENCES}

Adolphs, U. \& Wendler, G., 1995: A pilot study on the interactions between katabatic winds and polynyas at the Adélie Coast, Eastern Antarctica. Antarct. Sci. 7: 307314.

BAIL, F.K., 1957: The katabatic winds of Adelie Land and King George V Land. Tellus 9: 201-208.

Bindoff, N.L., Warner, M.J. \& Nicol, S., 1997: The Antarctic Margin Experiment. Int. WOCE Newsl. 26: 36-38.

Carmack, E.C., 1977: Water characteristics of the Southern Ocean south of the Polar Front. In Angel, M. (Ed.): VOYAGE OF DISCOVERY: GEORGE DEACON TOTH ANNIVERSARY VOLUME. Deep-Sea Research, Pergamon Press, Oxford: 15-41.

CaVAeIERI, D.J. \& Martin, S., 1985: A passive microwave study of polynyas along the Antarctic Wilkes Land coast. In Jacobs, S.S. (Ed.): OCEANOLOGY OF THE CONTINENTAL ANTARCTIC SHELF. Antarct. Res. Ser. American Geophysical Union, Washington: 227252

Gloersen, P., Campbell, W.S., Cavalieri, D.J., Comiso, J.C., Parkinson, C.L. \& ZWALly, H.J., 1992: Satellite passive microwave observations and analysis. National Aeronautics and Space Administration, Washington, DC, NASA SP-511: 290 pp.
Gordon, A.L. \& TCHernis, P., 1972: Waters of the continental margin off Adelie coast, Antarctica. In Hayes, D.E. (Ed.): ANTARCTIC OCEANOLOGYII: THE AUSTRALIANNEW ZEALAND SECTOR. Antarct. Res. Ser. American Geophysical Union, Washington: 59-69.

Gras, J.L., Derek, N., Tindale, N.W. \& Dick, A.L., 1999: BASELINE ATMOSPHERIC PROGRAM AUSTRALIA 1996. Bureau of Meteorology and CSIRO Division of Atmospheric Research: 146 pp.

JaCkEtT, D.R. \& MCDougall, T.J., 1997: A neutral density variable for the world's ocean. J. Phys. Oceanogr. 27(2): 237-263.

Manabe, S., Bryan, K. \& Spelman, M.J., 1990: Transient response of a global ocean-atmosphere model to a doubling of atmospheric carbon dioxide. J. Phys. Oceanogr. 20: 722 749.

Manabe, S., Stouffer, R.J., Spelman, M.J. \& Bryan, K., 1991: Transient responses of a coupled ocean-atmosphere model to gradual changes of atmospheric $\mathrm{CO}_{2}$. Part I : annual mean response. J. Climate 4: 785-818.

Massom, R., Harris, P., Michael, K. \& Potter, M., 1998: The distribution and formative processes of latent heat polynyas in East Antarctica. Ann. Glac. 27: 420-426.

Orsi, A.H., Johnson, G.C. \& BulLister, J.L., 1999: Circulation, mixing and production of Antarctic Bottom Water. Progr. Oceanogr: in press.

RinTovL, S.R., 1998: On the origin and influence of Adelie Land Bottom Water. In Jacobs, S. \& Weiss, R. (Eds): OCEAN, ICE, AND ATMOSPHERE: INTERACTIONS AT THE ANTARCTIC CONTINENTAL MARGIN. Antarct. Res. Ser. 75. American Geophysical Union, Washington: 151I71.

Rosenberg, M., Bray, S., Bindoff, N.L., Rintoul, S.R., Johnston, N., Bell, S. \& Towler, P., 1997: Aurora Australis marine science cruises AU9501, AU9604 and AU9601 - oceanographic field measurements and analysis, intercruise comparisons and data quality notes. Antarctic CRC, Hobart 12: 150 pp.

Worthington, L.V., 1981: The water masses of the worlds ocean: some results of a fine-scale census. In Warren, B.A. \& Wunsch, C. (Eds): EVOLUTION OF PHYSICAL OCEANOGRAPHY. MIT Press, Cambridge: 42-69.

Zwally, H.J., Comiso, J.C. \& Gordon, A.L., 1985: Antarctic offshore leads and polynyas and oceanographic effects. In Jacobs, S.S. (Ed.): OCEANOLOGY OF THE ANTARCTIC CONTINENTAL SHELF. Antarct. Res. Ser. American Geophysical Union, Washington: 203-226.

(accepted 5 July 1999) 